\title{
Infectious keratitis: findings from a retrospective review in the central zone of Sarawak
}

Koay Jiah Bou, Tan Teng Siew, Chua Ter Wei, Tan Li Mun

Department of Ophthalmology, Hospital Sibu, Sibu, Sarawak, Malaysia

\section{Abstract}

Introduction: Infectious keratitis is caused by inflammation of the cornea from an infectious pathogen that usually results in corneal scarring. It is a major cause of visual impairment globally. The management of infectious keratitis is challenging, and unfortunately, there is no proper study on this issue in the central zone of Sarawak to date.

Purpose: To identify the demographic characteristics, risk factors, and etiological agents of patients with infectious keratitis in Sibu Hospital, Sarawak, Malaysia. Design of the study: Retrospective study.

Materials and methods: Data were collected and reviewed from medical records of all patients with infectious keratitis in Sibu Hospital from January 2013 up to May 2018.

Results: A total of 139 patients (143 eyes/cases) were included in the study. The average age of affected individuals was 47.39 years. The most frequently affected patients fell within the age group of $21-30$ years (18.9\%). The male-to-female ratio was $1.65: 1$, with $61.5 \%$ of patients being males and $38.5 \%$ being females. Seventy-four cases were noted to have predisposing factors before the manifestation of symptoms. The commonest predisposing factors were ocular trauma (55.4\%), followed by contact lens wear (29.7\%), recent ocular surgery (13.5\%), and a recent history of swimming (7.4\%). At least one pathogen was isolated in $63.1 \%$ of the 38 cases that were tested for corneal scraping culture and sensitivity. Pseudomonas aeruginosa was identified as the most common causative pathogen in our study. Conclusion: Ocular injury stood out as the most common risk factor for infectious keratitis in this study and Pseudomonas aeruginosa was the most common

Correspondence: Dr. Koay Joah Bou, MD, Hospital Sibu, Batu 5ํㅡㄹ, Jalan Ulu Oya, 96000 Sibu, Sarawak, Malaysia.

E-mail:jiahbou@gmail.com 
etiological pathogen. A good grasp of local epidemiology and microbial profile of infectious keratitis is essential in aiding and guiding the management of infectious keratitis in hopes of better outcomes for all affected patients.

Keywords: infectious keratitis, Malaysia, ocular injury, Pseudomonas aeruginosa, Sarawak

\section{Keratitis berjangkit: penemuan dari kajian retrospektif di zon pusat Sarawak}

\section{Abstrak}

Pengenalan: Keratitis berjangkit disebabkan oleh keradangan kornea dari patogen berjangkit yang biasanya mengakibatkan parut kornea. Ia adalah penyebab utama kerosakan penglihatan di seluruh dunia. Rawatan keratitis adalah mencabar, dan malangnya, tidak ada kajian yang sewajarnya mengenai isu ini di zon pusat Sarawak hingga kini.

Tujuan: Untuk mengenal pasti ciri-ciri demografi, faktor risiko, dan agen etiologi pesakit dengan keratitis berjangkit di Hospital Sibu, Sarawak, Malaysia.

Reka bentuk kajian: Kajian retrospektif.

Bahan dan kaedah: Data dikumpulkan dan diperiksa dari rekod perubatan semua pesakit dengan keratitis berjangkit di Hospital Sibu dari Januari 2013 sehingga Mei 2018.

Keputusan: Sebanyak 139 pesakit (143 mata / kes) telah dimasukkan ke dalam kajian ini. Umur purata individu terjejas ialah 47.39 tahun. Pesakit yang paling kerap terjejas jatuh dalam kumpulan umur 21-30 tahun (18.9\%). Nisbah lelaki-ke-wanita ialah 1.65: 1, dengan $61.5 \%$ pesakit lelaki dan $38.5 \%$ wanita. Tujuh puluh empat kes telah dikenal pasti mempunyai faktor-faktor risiko tertentu. Faktor kecenderungan yang paling biasa adalah trauma okular (55.4\%), diikuti dengan memakai kanta sentuh (29.7\%), pembedahan okular yang terkini (13.5\%), dan sejarah berenang dalam masa terdekat (7.4\%). Sekurang-kurangnya satu patogen telah diasingkan dalam $63.1 \%$ daripada 38 kes yang diuji untuk kultur dan sensitiviti kornea. Pseudomonas aeruginosa dikenalpasti sebagai patogen penyebab yang paling kerap ditemui dalam kajian kami.

Kesimpulan: Kecederaan mata adalah faktor risiko yang paling kerap untuk keratitis berjangkit dan dalam kajian ini Pseudomonas aeruginosa adalah patogen yang paling menonjol. Pemahaman terperinci terhadap epidemiologi tempatan dan profil mikroba keratitis yang berjangkit adalah penting untuk membantu rawatan 
keratitis berjangkit dengan harapan akan mendapat hasil yang lebih baik untuk semua pesakit.

Kata kunci: keratitis berjangkit, Malaysia, trauma okular, Pseudomonas aeruginosa, Sarawak

\section{Introduction}

Infectious keratitis is caused by inflammation of the cornea from an infectious pathogen that usually results in corneal scarring. Infectious keratitis is an important preventable cause of corneal opacity leading to visual impairment and even blindness. Corneal opacities account for approximately $4 \%$ of blindness globally, ranking fourth on the list of main causes. ${ }^{1}$ It has an annual incidence of 27.6 per 100,000 people in the USA and its trend is increasing. ${ }^{2}$ It is a common yet clinically challenging condition, and ophthalmologists frequently face a dilemma when managing it. Severe infectious keratitis warrants hospital admission and intensive treatment, adding to the burden of health care costs. A good grasp of the epidemiology of the condition can often be useful in its management. Unfortunately, there have been no studies regarding infectious keratitis in the central zone of Sarawak to date.

Sibu is a major river port city in the central region of Sarawak, which is located in the tropical island of Borneo. It covers an area of 129.5 square kilometres. The climate in Sibu is classified as tropical, with an average temperature of $27^{\circ} \mathrm{C}$ and relative humidity. The region consists predominantly of alluvial plains and peat swamp forests.

This study aims to determine the demographic characteristics, predisposing factors, microbial profile, and final outcomes of patients with infectious keratitis in the central zone of Sarawak. Furthermore, it probed into the understanding of patients' attitude and health awareness.

\section{Materials and methods}

Sibu Hospital is the second largest government hospital in Sarawak, Malaysia. It serves as the tertiary referral centre for the central zone of Sarawak and provides medical services to a population of about 500,000, including suburban populations. Cases of infectious keratitis are managed by ophthalmologists in Sibu, but complicated cases are referred to Kuching or Kuala Lumpur for subsequent management. Nursing care is provided by experienced staff in the hospital and investigations such as corneal specimen culture and sensitivity are performed by a microbiological laboratory to assist in management.

This study was approved by the Malaysian National Institute of Health and was 
registered in the National Medical Research Registry (NMRR-18-1621-42441). This is a retrospective descriptive study which targeted all patients treated for infectious keratitis in Sibu Hospital from January 2013 until May 2018. Patients came from Sibu and neighbouring areas such as Kapit, Dalat, Mukah, and Matu. Data were collected from medical and laboratory records.

Cases with missing medical records were excluded from this study. Data on

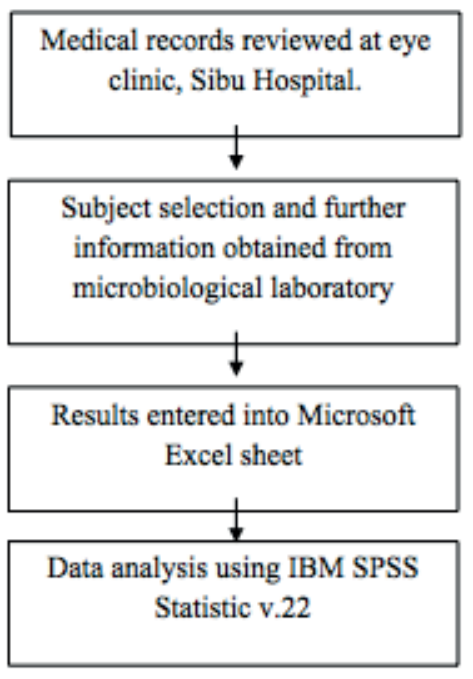

Fig. 1. Flow chart of the study. demography, predisposing factors, presentation interval, admission, duration of hospital stay, clinical manifestation of infectious keratitis, biological specimen cultures and sensitivity, visual outcome, and management of the condition and its complications were collected and analysed.

Both descriptive analysis and specific tests were performed using IBM SPSS Statistic v.22. The Chi-square test was used to analyse the significance of association between two categorical data, whereas the Wilcoxon Signed Rank test was used to compare the ordinal data of a similar group. The Mann-Whitney test was performed to test associative factors with best-corrected visual acuity (BCVA) at diagnosis. A p-value of $<0.05$ indicates statistical significance. A flow chart is shown in Figure 1.

\section{Results}

\section{Sociodemographic}

A total of 139 patients were enrolled in this study from January 2013 to May 2018. This study demonstrated that from the total of 143 eyes (cases) collected, $97.2 \%$ had unilateral eye involvement, whereas $2.8 \%$ (4 patients) had bilateral eye involvement. The mean age of cases was $47.39 \pm 20.3$ years, with a range of patients from 11 to 91 years old. The peak age group fell at 21-30 years of age (18.9\%), whereas the least patients were in the 91-100 age group (1.4\%), as shown in Figure 2. Eighty-eight cases $(61.5 \%)$ were male and $55(38.5 \%)$ were female, with a male-to-female ratio of 1.65:1.

Most of the cases were among local populations (98.6\%), with Iban (40.6\%) being the majority, followed by Chinese (25.9\%), Melanau (16.8\%), Malay (12.5\%), and others (6.2\%). A higher percentage of cases, $51.8 \%$, were from rural areas, mainly Kapit, Dalat, and Daro, as compared to $48.2 \%$ from the urban area. 




Fig. 2. Distributions of patients with infectious keratitis according to age group in Sibu Hospital.

Seventy-four cases (51.7\%) were identified to have predisposing factors prior to the onset of infectious keratitis. The most common was a history of recent ocular trauma (55.4\%), followed by contact lens wear (29.7\%), recent eye surgery $(13.5 \%)$ - most of which were related to cataract extraction -, and recent history of swimming in the river (1.4\%).

The complete data regarding demographics and predisposing factors is shown in Table 1.

\section{Clinical features}

Among the 135 cases presented in the eye clinic, $44.4 \%$ came within 5 days of onset, whereas the remaining $55.6 \%$ came after 5 days. Sixty-four cases $(44.7 \%)$ were hospitalized and, among these, 38 (59.4\%) had prolonged hospitalisation, whereas $26(40.6 \%)$ had a hospital stay of less than 7 days.

More than half, $57.6 \%$ had a large corneal epithelial defect $(>2 \mathrm{~mm})$. Of the cases, $78.8 \%$ involved a centrally localized, while only $21.2 \%$ involved the peripheral cornea. Approximately one-third (30.7\%) had hypopyon. Recurrence of infectious keratitis was observed in $5.6 \%$ of cases.

BCVA was assessed upon diagnosis with Snellen chart and was subcategorized into good (better than 6/18), mild-to-moderate visual impairment (6/18 to 3/60), and severe visual impairment (worse than $3 / 60$ ). Of the cases, $46.4 \%$ had severe 
Table 1. Demographic characteristics and predisposing factors of cases with infectious keratitis in Sibu Hospital

\begin{tabular}{|l|l|}
\hline Demographic characteristics & N \\
\hline Age (years) & 143 \\
\hline Age group (years) & 143 \\
$11-20$ & $12(8.4 \%)$ \\
$21-30$ & $27(18.9 \%)$ \\
$31-40$ & $17(11.9 \%)$ \\
$41-50$ & $22(15.4 \%)$ \\
$51-60$ & $21(14.7 \%)$ \\
$61-70$ & $20(14 \%)$ \\
$71-80$ & $17(11.9 \%)$ \\
$81-90$ & $5(3.5 \%)$ \\
$91-100$ & $2(1.4 \%)$ \\
\hline Gender & 143 \\
Male & $88(61.5 \%)$ \\
Female & $55(38.5 \%)$ \\
\hline Ethnicity & 143 \\
Malay & $18(12.5 \%)$ \\
Chinese & $37(25.9 \%)$ \\
Iban & $58(40.6 \%)$ \\
Melanau & $24(16.8 \%)$ \\
Others & $6(4.2 \%)$ \\
\hline Nationality & 143 \\
Malaysian & $141(98.6 \%)$ \\
Non-Malaysian & $2(1.4 \%)$ \\
\hline Geographical area & 139 \\
Urban & $67(48.2 \%)$ \\
Rural & $72(51.8 \%)$ \\
\hline Predisposing factors & 74 \\
Contact lens wear & $22(29.7 \%)$ \\
Recent trauma & $41(55.4 \%)$ \\
Recent eye surgery & $10(13.5 \%)$ \\
Recent swimming & $1(1.4 \%)$ \\
\hline & \\
\hline
\end{tabular}

visual impairment upon diagnosis, followed by $31.9 \%$ with good visual acuity, and $21.7 \%$ with mild-to-moderate visual impairment. The complete data of clinical features and BCVA upon diagnosis, 1 month, and 3 months were tabulated in Table 2.

A total of 41 cases had recent ocular trauma prior to the development of infectious keratitis. Most common age groups were between 51-60 years and 61-70 years. Male patients were more commonly affected, accounting for $82.9 \%$. 
Table 2. Clinical features of infectious keratitis cases in Sibu Hospital

\begin{tabular}{|l|l|}
\hline Clinical features & N \\
\hline Presentation interval to Sibu Hospital eye clinic & 135 \\
5 days or less & $60(44.4 \%)$ \\
More than 5 days & $75(55.6 \%)$ \\
\hline Duration of hospital stay & 64 \\
7 days or less & $26(40.6 \%)$ \\
More than 7 days (prolonged) & $38(59.4 \%)$ \\
\hline Laterality & 143 \\
Right & $67(46.9 \%)$ \\
Left & $76(53.1 \%)$ \\
\hline Size of keratitis & 132 \\
Small $(<2$ mm) & $56(42.4 \%)$ \\
Large $(>2$ mm) & $76(57.6 \%)$ \\
\hline Location & 132 \\
Peripheral & $28(21.2 \%)$ \\
Central & $104(78.8 \%)$ \\
\hline Hypopyon & 137 \\
Present & $42(30.7 \%)$ \\
Absent & $95(69.3 \%)$ \\
\hline Recurrence & 142 \\
Yes & $8(5.6 \%)$ \\
No & $134(94.4 \%)$ \\
\hline BCVA upon diagnosis & 138 \\
Good (>6/18) & $44(31.9 \%)$ \\
Mild-moderate impairment $(<6 / 18 ; \geq 3 / 60)$ & $30(21.7 \%)$ \\
Severe impairment $(<3 / 60)$ & $64(46.4 \%)$ \\
\hline BCVA after 1 month & 123 \\
Good (>6/18) & 52 \\
Mild-moderate impairment $(<6 / 18 ; \geq 3 / 60)$ & $26(21.1 \%)$ \\
Severe impairment $(<3 / 60)$ & $43(35 \%)$ \\
\hline BCVA after 3 months & $34(41.5 \%)$ \\
Good (> 6/18) & \\
Mild-moderate impairment $(<6 / 18 ; \geq 3 / 60)$ & $83.6 \%)$ \\
Severe impairment $(<3 / 60)$ & \\
\hline
\end{tabular}

BCVA: best corrected visual acuity 
Patients who presented within 5 days of severe visual impairment upon diagnosis were shown to be statistically significant (Z-score -2.082, $p=0.037$ ), as seen in Table 3. This may illustrate that patients in Sibu and neighbouring areas tend to only seek medical attention when their vision deteriorates severely. This study also showed statistical significance in regards to BCVA at time of diagnosis and keratitis that is located centrally $(p=0.000)$, of larger size $(p=0.000)$, and with the presence of hypopyon $(p=0.000)$.

There was no significant association between predisposing factors and BCVA at diagnosis of infectious keratitis (Table 4).

In this study, 32 cases (25.2\%) with large infiltrate had hypopyon, whereas 10 cases (7.9\%) with small infiltrate had hypopyon. There was a statistically significant association between the size of corneal infiltration and the presence of hypopyon, showing that larger corneal infiltration tends to be accompanied with hypopyon $(\mathrm{N}=127, \mathrm{p}=0.001)$. On the other hand, 40 cases with centrally located infiltrate had hypopyon, while only 2 peripheral infiltrate cases had hypopyon. Hence, centrally located corneal infiltration had a higher association with presence of hypopyon $(\mathrm{N}=127, \mathrm{p}=0.001)$.

There was a statistically significant visual improvement between the presenting BCVA and post-treatment BCVA at 1 month $(\mathrm{N}=120, \mathrm{Z}=-4.777, \mathrm{p}<0.05)$.

\section{Investigations}

Only 39 cases had a full blood count test and 33.3\% of them had an elevated white cell count (> $12 \times 10^{3} / \mathrm{uL}$ ). Among the 47 cases which were investigated for Gram staining of a corneal specimen, detection of Gram-negative and Gram-positive organisms was $12.8 \%$ and $10.6 \%$, respectively. No organisms were detected in $59.6 \%$ of the cases, while $17 \%$ were not available due to an unsatisfactory smear. Details of the investigations are shown in Table 5.

Fifty-seven $(63.1 \%)$ cases tested for corneal scraping culture and sensitivity revealed bacterial growth, while mixed growth and fungi contributed $1.8 \%$ each. Pseudomonas aeruginosa was the most common pathogen (22 cases, 57\%), followed by Streptococcus pneumoniae (3 cases, 7\%), coagulase-negative Staphylococcus sp. (2 cases, 5\%), and Staphylococcus aureus (1 case, 2\%). Other less common pathogens, such as Acinetobacter sp., Aeromonas spp., Brevundimonas vesicularis, Cronobacter sp., Enterobacter sp., Moraxella sp., Serratia marcescens, Corynebacterium sp., and Fusarium sp. were isolated. Only one case had mixed growth of Streptococcus pneumonia and Enterobacter sp.

\section{Contact lens-related corneal ulcer}

There were 22 cases of contact lens-related corneal ulcer (CLRCU). Most contact lenses, contact lens solutions, and casings were sent for culture and sensitivity to investigate microorganism growth. Twelve (54.5\%) cases grew Pseudomonas aeruginosa and one grew Staphylococcus aureus. 
Table 4. Association between BCVA at diagnosis and predisposing factors in infectious keratitis in Sibu Hospital

\begin{tabular}{|c|c|c|}
\hline \multicolumn{3}{|c|}{ BCVA at Diagnosis } \\
\hline & $\mathbf{N}$ & $\mathbf{p}$ \\
\hline \multicolumn{3}{|c|}{ Presentation interval to Sibu Hospital eye clinic $(\mathrm{N}=135)$} \\
\hline $\begin{array}{l}\text { Within } 5 \text { days } \\
\text { More than } 5 \text { days }\end{array}$ & $\begin{array}{l}60(44.4 \%) \\
75(55.6 \%)\end{array}$ & 0.037 \\
\hline \multicolumn{3}{|c|}{ Size of infiltrate $(\mathrm{N}=128)$} \\
\hline $\begin{array}{l}\text { Small }(<2 \mathrm{~mm}) \\
\text { Large }(>2 \mathrm{~mm})\end{array}$ & $\begin{array}{l}55(43.0 \%) \\
73(57.0 \%)\end{array}$ & 0.000 \\
\hline \multicolumn{3}{|c|}{ Location of infiltrate $(\mathrm{N}=128)$} \\
\hline $\begin{array}{l}\text { Central } \\
\text { Peripheral }\end{array}$ & $\begin{array}{l}100(78.1 \%) \\
28(21.9 \%)\end{array}$ & 0.000 \\
\hline \multicolumn{3}{|c|}{ Hypopyon ( $=133$ ) } \\
\hline $\begin{array}{l}\text { Present } \\
\text { Absent }\end{array}$ & $\begin{array}{l}41(30.8 \%) \\
92(69.2 \%)\end{array}$ & 0.000 \\
\hline
\end{tabular}

\begin{tabular}{|c|c|c|c|c|}
\hline & \multicolumn{3}{|c|}{ Visual acuity, n (\%) } & \multirow[t]{2}{*}{$\mathbf{p}$} \\
\hline & Good & Mild-Moderate & Severe & \\
\hline Predisposing factors & & & & 0.773 \\
\hline Contact lens & $6(8.1 \%)$ & $2(2.7 \%)$ & 14 (18.9) & \\
\hline Recent ocular trauma & $11(14.9 \%)$ & $10(13.5 \%)$ & $20(27.0 \%)$ & \\
\hline Recent ocular surgery & $3(4.1 \%)$ & $2(2.7 \%)$ & $5(6.8 \%)$ & \\
\hline Recent swimming & $0(1.6 \%)$ & $0(0 \%)$ & $1(0 \%)$ & \\
\hline
\end{tabular}


Table 5. Investigations performed on infectious keratitis cases in Sibu Hospital

\begin{tabular}{|l|l|}
\hline Investigations & \\
\hline White cell count & 39 \\
\hline Elevated (> 12 x 103/uL) & $13(33.3 \%)$ \\
Within normal range & $26(66.7 \%)$ \\
\hline Gram stain of corneal scraping & 47 \\
\hline Gram-positive organism & $5(10.6 \%)$ \\
Gram-negative organism & $6(12.8 \%)$ \\
No organism seen & $28(59.6 \%)$ \\
Unsatisfactory smear & $8(17.0 \%)$ \\
\hline Smear for KOH preparation & 14 \\
\hline Positive & $0(0 \%)$ \\
Negative & $13(92.9 \%)$ \\
Contaminated & $1(7.1 \%)$ \\
\hline Corneal scraping cultures & 57 \\
\hline Bacteria & $36(63.1 \%)$ \\
Mixed growth & $1(1.8 \%)$ \\
Fungi & $1(1.8 \%)$ \\
Sterile & $19(33.3 \%)$ \\
\hline
\end{tabular}

potassium hydroxide

\section{Management}

Only 51 cases (36.4\%) completed the full treatment course and 89 cases (63.6\%) defaulted treatment or follow-up. Most cases were commenced on topical antibiotics ( $81.1 \%), 24.5 \%$ on topical antivirals, and $9.1 \%$ on antifungals.

\section{Complications}

Fifteen cases (10.5\%) were identified to be complicated with a corneal perforation (Table 6). Amongst these, 7 cases proceeded with an evisceration, 6 cases (40\%) underwent gluing bandage contact lens, and 1 case (6.67\%) had a tarsorrhaphy. There was a patient in this study who refused any form of surgical intervention whom developed phthisis bulbi as a complication of infectious keratitis.

\section{Discussion}

Risk factors and causative agents for infectious keratitis may vary from time to time, depending on the climate, geography, and population of an area. ${ }^{1}$ Low socioeconomic status and geographical location are other factors to consider. Patients with low socioeconomic status are more prone to malnutrition and poor hygiene. 
Table 6. Complications and further management of infectious keratitis cases in Sibu Hospital

\begin{tabular}{|l|l|}
\hline Complications and further management & N \\
\hline Perforation & $15(10.5 \%)$ \\
\hline Evisceration & $7(4.9 \%)$ \\
\hline Gluing with bandaged contact lens & $6(4.2 \%) ;$ \\
\hline Tarsorrhaphy & $1(0.7 \%)$ \\
\hline Phthisis bulbi & $1(0.7 \%)$ \\
\hline
\end{tabular}

Delayed presentation for a medical consultation is more likely in this group of patients. Ravinder et al. evidenced this in 2016, reporting that $60 \%$ of the cases were of low socioeconomic status. ${ }^{2}$ Without adequate infrastructure and road systems in rural areas, patients have difficulty seeking medical treatment as they must travel for hours or even days. This is usually commonly seen in developing countries. However, it is inconclusive in this study and this limitation may be reduced by having a larger sample size in future studies.

Ocular trauma, which comprised $27.6 \%$ of all cases, was a common cause of corneal ulcers in the younger population and in males. ${ }^{1} \mathrm{~A}$ study by Dandona and Dandona showed similar findings. ${ }^{3}$ Nonsurgical ocular trauma is the major predisposing factor in corneal ulcers in developing countries, $65.4 \%{ }^{4}$. This was found to be consistent with our results that illustrated ocular trauma to be the most common factor, accounting for $55 \%$ of cases, of which patients were predominantly male (82.9\%). However, a study done by Omar et al. in Malaysia found that the contact lens wear contributed to corneal ulcers more than other factors. ${ }^{3}$ This is probably due to the fact that the aforementioned study involved an urban population, whereas our patients were mostly from suburban areas. Keshav et al. found that only a few patients developed corneal ulcer after surgery (8 of 1198)..$^{5}$ There were only two foreigners involved in this study and both had corneal injury prior to the development of infectious keratitis. This is not consistent with the results by Ratnalingam et al. in 2017, who reported that most cases in East Malaysia were related to contact lens. ${ }^{6}$

Diabetes is shown to be a mild predisposing factor in other studies. It was reported that there was a low incidence of diabetes mellitus among similar cases. ${ }^{4,7}$ This study showed that only 20 patients had diabetic mellitus, accounting for only $13.9 \%$ of the cases. Only two patients, who were on long-term steroid therapy, had infectious keratitis. This suggests that immunosuppression may contribute minimally to the occurrence of infectious keratitis.

Slightly more than half the cases (55.6\%) in our study presented after 5 days of onset of symptoms; this is longer than the presenting time in two local studies, 4.67 days and 4.7 days in Omar et al. and Hooi and Hooi, respectively. ${ }^{1,8}$ This delay can 
probably be attributed to the difficulty faced by patients travelling to Sibu Hospital eye clinic as a result of underdeveloped infrastructure in Sarawak.

Of the cases, $57.6 \%$ had infectious keratitis with an infiltrate larger than $2 \mathrm{~mm}$. This is comparable with the findings by Omar et al. and Kadir et al., who reported $60.9 \%$ and $75.8 \%$, respectively. ${ }^{1,9}$ This may reveal that, in Malaysia, most cases presented at a more severe stage; this should alert health care providers to increase awareness regarding ocular health in the community. Hypopyon was observed more frequently in infectious keratitis with a large and central infiltrate; these results are consistent with two local studies. ${ }^{1,8}$ Hence, the presence of hypopyon can be considered as an indicator for severity.

We found that there was no single predisposing factor that resulted in worse visual impairment upon diagnosis, which is consistent with another local study by Omar et al. ${ }^{1}$ Therefore, the information on precedent risk factors could be helpful in educating the local population for preventing infectious keratitis, but not for predicting its impact on visual impairment.

Significant diversity of pathogens is implicated in infectious keratitis, and it is suggested that climate, environment, economy, and other risk factors contribute to the variations seen across nations. . $^{410-13}$

A Malaysian study on CLRCU shows that $84.6 \%$ of corneal scraping cultures grew Pseudomonas aeruginosa. ${ }^{14}$ This is consistent with our results, which showed $59 \%$ of CLRCU grew the same bacteria. In developed countries, such as Australia, New Zealand, and the United Kingdom, as well as in developing countries, such as Brazil and Malaysia, studies have shown that Pseudomonas aeruginosa is a commonly isolated bacterium in corneal ulcers. ${ }^{6,8,10,15,16}$ However, Gram-positive bacteria are more common according to studies in Canada, North America, Nepal, Paraguay, Europe, United Kingdom, United States, and New Zealand. ${ }^{17-26}$ Other common bacteria include Staphylococcus epidermidis, Staphylococcus aureus, Streptococcus pneumoniae, Acinetobacter baumannii, and Serratia marcescens. Our study showed a wide range of isolated microorganisms, and less common pathogens were implicated.

Fungi were reported as a major cause of infectious keratitis in Asia, ultimately leading to blindness, accounting for $44 \%$ of central ulcers. ${ }^{27}$ Two studies in India described fungi as the leading causative organism, at $26.4 \%$ to $34.4 \%{ }^{28,29}$ Fungal keratitis is common in developing countries, especially in tropical countries. ${ }^{11-}$ ${ }^{13}$ Filamentous fungi, e.g. Fusarium sp. and Aspergillus spp., were found to be the most common fungi responsible for fungal keratitis., ${ }^{4,6,12,13,28}$ However, in our study, only one patient was found to have fungal keratitis proven by culture, caused by Fusarium sp. Despite low detection of fungal infection in cultures, 13 cases $(9.1 \%)$ were commenced on topical antifungals and 8 cases $(5.6 \%)$ with systemic antifungals empirically due to severe corneal infiltration. Poor culture findings of fungi in our study can be attributed to poor corneal scraping technique leading to unsatisfactory samples.

Three patients, treated as keratitis caused by Acanthamoeba were treated with 
topical propamidine, chlorhexidine, and covered with topical ciprofloxacin for months. Only one of them was contact lens-related. Two patients who completed treatment had severely impaired vision and achieved 6/9-6/12, while another patient, who presented late with impending perforation, ended with phthisis bulbi.

Empirical broad-spectrum treatment using dual therapy of gentamicin and second- or third-generation cephalosporin is the primary management. ${ }^{5,30}$ Therapy can later be tailored to culture and sensitivity of corneal scraping and clinical response. Considering the significant diversity of implicated microorganisms, treatment guidelines are not applicable universally, but must be tailored to geographical location. ${ }^{8}$ In Malaysia, most cases are started on ceftazidime and fortified gentamicin eyedrops. ${ }^{8}$ Monotherapy using a fourth-generation fluoroquinolone for small peripheral ulcers is practised in some centres, including Sibu Hospital, but may not be as effective as the aforementioned therapy and may carry the risk of antibiotic resistance. ${ }^{30,31}$

Severe infectious keratitis may require surgical intervention such as penetrating keratoplasty. It is indicated in large corneal perforations or any perforations with persistent deterioration despite antibiotic therapy. ${ }^{32}$ This is described in a study by Dandona et al. in $12.2 \%$ of cases that had penetrating keratoplasty. In contrast, small perforations can be managed with a glue adhesive to help restore the integrity of the anterior segment temporarily. ${ }^{32}$ In our study, seven patients underwent evisceration, whereas six patients underwent gluing of the small perforation. No patients had penetrating keratoplasty. This is likely due to loss of data, as medical records were dispensed to patients referred for surgical interventions in ophthalmology centres with corneal transplantation services.

Our study did not show any statistically significant good visual outcome for any predisposing factors. This is different from the study by Hooi and Hooi showing that CLCRU have a better visual outcome compared to other predisposing factors. ${ }^{8}$ Cases in our study generally had severe visual impairment at diagnosis (46.4\%) and approximately $35 \%$ of cases remained severely visually impaired after a month of treatment. This is much higher than the results shown in a study done by Ismail et al., which found that approximately $10 \%$ of cases remained blind after treatment, while $9.6 \%$ remained visually impaired. This can possibly be attributed to the lack of health awareness among the residents in our study population. Reluctant to seek medical attention, patients in suburban areas tend to get treatment only when their condition has become severe enough to cause poor vision. This explains why more patients in our study had poor vision at diagnosis as well as a poorer prognosis.

Infectious keratitis was complicated with corneal perforation in $10.5 \%$ of the cases in our study, a percentage similar to the one reported by Hooi and Hooi in 2005, who found that $12.9 \%$ of affected eyes were complicated with corneal perforation and were more commonly related to Pseudomonas aeruginosa infections ${ }^{8}$. Infection by pseudomonal organisms is rapid and can progress rapidly as they possess lytic enzymes. If left untreated, descemetocele forms within 2-5 days, leading to 
perforation. ${ }^{33}$ The same study showed that $1 \%$ of cases developed endophthalmitis related to Citrobacter diversus. Our study did not report any affected eyes with complicated endophthalmitis.

\section{Conclusion}

Ocular injury was identified as the primary risk factor for infective keratitis in this study, with Pseudomonas aeruginosa being the most common isolated pathogen. A proper understanding of the latest epidemiology and microbiological profile of infectious keratitis in the central zone of Sarawak is crucial in aiding the management of these cases in hopes of a better final visual outcome.

\section{Acknowledgements}

We wish to thank Dr. Kamilah Binti Dahian for her assistance and guidance in the completion of this study.

\section{References}

1. Omar N, Muna'aim MA, Saleh RM, Kasim ZM, Isa MM. An 8-year Retrospective Review of Microbial Keratitis in A Secondary Referral Centre in Malaysia. MJMHS. 2017;13(2):47-57.

2. Ravinder K, Madhav MV, Archaᄀna J, Jadhav Pandurang. Clinical evaluation of corneal ulcer among patients attending teaching hospital. Int J Con 7 temp Med Res. 2016;3(4):949-952.

3. Dandona R, Dandona L. Review of findings of the Andhra Pradesh Eye Disease Study: policy implications for eye-care services. Indian J Ophthalmol. 2001;49(4):215- 234.

4. Srinivasan M, Gonzales CA, George C, et al. Epidemiology and aetiological diagnosis of corneal ulceration in Madurai, south India. Br J Ophthalmology. 1997;81(11):965-971.

5. Keshav BR, Zacheria G, Ideculla T, Bhat V, Joseph M. Epidemiological Characteristics of Corneal ulcers in South Sharqiya region. Oman Med J. 2008;23(1):34-39.

6. Ratnalingam V, Umapathy, T, Sumugam K, Hanafi H, Retnasabapathy S. Microbial keratitis in West and East Malaysia. International Eye Science. 2017;17(11):1989-1992.

7. Basak SK, Basak S, Mohanta A, Bhowmick A. Epidemiological and microbiological diagnosis of suppurative keratitis in Gangetic West Bengal, eastern India. Indian J Ophthalmol. 2005;53(1):17-22.

8. Hooi SH, Hooi ST. Culture-Proven Bacterial Keratitis in a Malaysia General Hospital. Med J Malaysia. 2005;60(5):614- 623.

9. Kadir AJ, Samsudin A, Fauzi A, Abidin ZZ. Review of corneal ulcers at University Malaya Medical Centre. Int J Ophthalmol. 2008;8(12):2376-80.

10. Comarella JD, Saraiva PGC, Saraiva FP. Corneal ulcer: a retrospective study of cases seen at the Hospital das Clínicas, Federal University of Espirito Santo. Rev Bras Oftalmol. 2015;74(2):76-80. 
11. Shah A, Sachdev A, Coggon D, Hossain P. Geographic variations in microbial keratitis: an analysis of the peer-reviewed literature. Br J Ophthalmology. 2015;95:762-767.

12. Karsten E, Watson SL, Foster LJR. Diversity of Microbial Species Implicated in Keratitis: A Review. Open Ophthalmol J. 2012;6:110-124.

13. Leck AK, Thomas PA, Hagan M, et al. Aetiology of suppurative corneal ulcers in Ghana and south India, and epidemiology of fungal keratitis. Br J Ophthalmol. 2015;86:1211-1215.

14. Goh PP, Shamala R, Chandamalar S, Tai XY, National Eye Database Study Group. Contact Lens-Related Corneal Ulcer: A Two-Year Review. Med J Malaysia. 2010;65:120-123.

15. Morgan PB, Efron N, Hill EA, Raynor MK, Withing MA, Tullo AB. Incidence of keratitis of varying severity among contact lens wearers. Br J Ophthalmol. 2005; 89:430-436.

16. Stapleton F, Keay LJ, Sanfilippos PG, Katiyar S, Edwards KP, Naduvilath T. Relationship Between Climate, Disease Severity, and Causative Organism for Contact Lens-Associated Microbial Keratitis in Australia. Am J Ophthalmol. 2007;144(5):690-698.

17. Wong T, Ormonde S, Gamble G, McGhee CN. Severe infective keratitis leading to hospital admission in New Zealand. Br J Ophthalmol. 2003;87(9):1103-1108.

18. Upadhyay MP, Karmacharya PCD, Koirala S, et al. Epidemiologic Characteristics, Predisposing Factors, and Etiologic Diagnosis of Corneal Ulceration in Nepal. Am J Ophthalmol. 1990;111:92-99.

19. Laspina F, Samudio M, Cilbils D, et al. Epidemiological characteristics of microbiological results on patients with infectious corneal ulcers: a 13-year survey in Paraguay. Graefes Arch Clin Exp Ophthalmol. 2004;242:202-209.

20. Bourcier T, Thomas F, Borderie V, Chaumeil C, Laroche L. Bacterial keratitis: predisposing factors, clinical and microbiological review of 300 cases. Br J Ophthalmol. 2003;87:834-838.

21. Schaefer F, Bruttin O, Zografos L, Guex-Crosier Yan. Bacterial keratitis: a prospective clinical and microbiological study. Br J Ophthalmol. 2001:85:842- 847.

22. Bennett HGB, Hay J, Kirkness CM, Seal DV, Devonshire P. Antimicrobial management of presumed microbial keratitis: guidelines for treatment of central and peripheral ulcers. $\mathrm{Br} \mathrm{J}$ Ophthalmol. 1998;82:137-145.

23. Khanal B, Deb M, Panda A, Sethi HS. Laboratory Diagnosis in Ulcerative Keratitis. Ophthalmic Res. 2006;37:123-127.

24. Asbell PA, Stenson SM. Ulcerative keratitis. Survey of 30 years' laboratory experience. Arch Ophthalmol. 1982;100(1):77-80.

25. Cheung J, Slomovic AR. Microbial etiology and predisposing factors among patients hospitalized for corneal ulceration. Can J Ophthalmol. 1995;30(5):251-255.

26. Alexandrakis G, Alfonso EC, Miller D. Shifting trends in bacterial keratitis in south Florida and emerging resistance to fluoroquinolones. Ophthalmology. 2000;107(8):1497-1502.

27. Sharma S, Srinivasan M, George C. The Current Status of Fusarium Species in Mycotic Keratitis in South India. Indian J Med Microbiol. 1993;11(2):140-147.

28. Bharathi MJ, Ramakrishnan R, Meenakshi R, Padmavathy S, Shivakumar C, Srinivasan M. Microbial Keratitis in South India: Influence of Risk Factors, Climate and Geographical Variation. Ophthalmic Epidemiol. 2007;14:61-69.

29. Shah A, Sachdev A, Coggon D, Hossain P. Geographic variations in microbial keratitis: an analysis of the peer- reviewed literature. Br J Ophthalmol. 2015;95:762-767. 
30. Benson WH, Lanier JD. Current diagnosis and treatment of corneal ulcers. Curr Opin Ophthalmol. 1998;9(IV):45-49.

31. Srinivasan M, Mascarenhas J, Prashanth CN. Distinguishing Infective versus Noninfective Keratitis. Indian J Ophthalmol. 2008; 56(3):203-207.

32. Al-Mujaini A, Al-Kharusi N, Thakral A, Wali UK. Bacterial Keratitis: Perspective on Epidemiology, Clinoco-Pathogenesis, Diagnosis and Treatment. Sultan Qaboos Univ Med J. 2009;9(2):184-195.

33. Ostler HB, Thygeson P, Okumoto M, Weddell J. Opportunistic ocular infections. Am Fam Physician. 1987;17:134-140. 